Revista Bioética

\title{
UPDATE
}

\section{Dialysis and the right to die}

Rodrigo Alexandre da Cunha Rodrigues ${ }^{1}$, Érica Quinaglia Silva ${ }^{2}$

1. Programa de Pós-Graduação em Saúde, Ambiente e Sociedade na Amazônia, Instituto de Ciências da Saúde, Universidade Federal do Pará (UFPA), Belém/PA, Brasil. 2. Programa de Pós-Graduação em Ciências e Tecnologias em Saúde, Departamento de Saúde Coletiva da Universidade de Brasília (UnB), Brasília/DF, Brasil.

\begin{abstract}
Chronic kidney disease reaches epidemic levels all over the world. In Brazil, more than 30 thousand people a year need dialysis treatment, specially hemodialysis. If, on the one hand, the lack of dialysis vacancies is the main problem, on the other hand, the number of cases of refusal and abandonment of dialysis has increased. This article deals precisely with this issue, based on subjects such as the meanings of life and death, autonomy and terminality. Some strategies which may reduce or even avoid treatment refusal and abandonment are early diagnosis, previous nephrological follow-up, multidisciplinary approach and humanization of dialysis services. If the patient's decision is irreversible, the informed consent form is essential. In addition, the expansion of the bioethics committees is important to protect health professionals and the interests of patients.
\end{abstract}

Keywords: Dialysis. Right to die. Personal autonomy.

\section{Resumo}

\section{Diálise e direito de morrer}

A doença renal crônica atinge níveis epidêmicos em praticamente todos os países. No Brasil, mais de 30 mil pessoas por ano precisam de tratamento dialítico, sendo mais comum a hemodiálise. Se, por um lado, a falta de vagas para diálise é o principal problema, por outro, têm crescido os casos de recusa e abandono do tratamento. Este artigo trata justamente dessa questão, a partir de temas como sentidos da vida e da morte, autonomia e terminalidade. Foram identificadas algumas estratégias que podem diminuir ou mesmo evitar a recusa e o abandono do tratamento, como diagnóstico precoce, acompanhamento nefrológico prévio, abordagem multidisciplinar e humanização dos serviços de diálise. Caso a decisão do paciente seja irreversível, o termo de consentimento livre e esclarecido é fundamental. Além disso, a expansão dos comitês de bioética é importante para proteger os profissionais de saúde e os interesses dos pacientes.

Palavras-chave: Diálise. Direito de morrer. Autonomia pessoal.

\section{Resumen}

\section{Diálisis y derecho a morir}

La enfermedad renal crónica alcanza niveles epidémicos en prácticamente todos los países. En Brasil, más de 30 mil personas por año requieren tratamiento de diálisis, siendo la hemodiálisis la más común. Si, por un lado, la falta de vacantes para diálisis es el problema principal, por otro, han aumentado los casos de rechazo y abandono del tratamiento. Este artículo aborda precisamente esta cuestión, a partir de temas como sentidos de la vida y de la muerte, autonomía y terminalidad. Se han identificado algunas estrategias que pueden disminuir o incluso evitar el rechazo y el abandono del tratamiento, como diagnóstico precoz, seguimiento nefrológico previo, abordaje multidisciplinario y humanización de los servicios de diálisis. En caso de que la decisión del paciente sea irreversible, el documento de consentimiento libre e informado es fundamental. Además, la expansión de los comités de bioética es importante para proteger a los profesionales de la salud y los intereses de los pacientes. Palabras clave: Diálisis. Derecho a morir. Autonomía personal. 
Chronic kidney disease: a worldwide epidemic

The increasing incidence of chronic kidney disease (CKD) is reaching epidemic levels worldwide, as a consequence of population aging and the increase of obesity, diabetes mellitus and hypertension. The spread of inappropriate habits, such as physical inactivity and hypercaloric, hypersodic, hyperglycemic and hyperlipidic diets ${ }^{1}$, contributes to this worldwide epidemic.

In Brazil, more than 30,000 people a year seek dialysis treatment, with hemodialysis being the most common and essential therapy for the maintenance of life when renal function reaches very critical levels ${ }^{2}$. However, due to the underfunding of the Sistema Único de Saúde - Unified Health System (SUS), the availability of dialysis did not increase proportionally to the demand, generating queues in states and municipalities.

For this reason, the elective initiation of dialysis therapy is increasingly difficult, and the emergency room is the main gateway for health services for patients with advanced CKD. In addition, many of these patients who seek emergency care in critical life and death situations are unaware that they suffer from CKD due to deficiencies in primary health care and lack of prior nephrological follow-up ${ }^{3}$. In cases of dialysis urgency when patients and family members agree with renal replacement therapy, there are three possible situations:

- Dialysis service is available, as well as a vacancy for treatment: the ideal situation, although increasingly rare;

- There is no Dialysis Service: All efforts focus on the difficult and often frustrating attempt to transfer the patient to another service offering treatment. Unfortunately, this is the most common situation and it is associated with high patient mortality and the consequent high degree of stress of the entire healthcare team;

- There is a dialysis service, but there are no vacancies: although the health professional has to face a structural problem about which he has little or no interference, from the ethical, moral and legal point of view, there is no doubt that lives need to be saved. For this purpose, the patient undergoes urgent dialysis, either in the intensive care unit (ICU), using a backup machine, or in the 4 th shift, which ends at dawn. After leaving the emergency situation, the patient remains hospitalized, usually for a long time, to ensure treatment until a vacancy occurs in a chronic outpatient hemodialysis program, when they are then discharged from hospital and undergo hemodialysis (on the homehemodialysis route) three times a week. This "saving" strategy sometimes causes administrative problems, as it crowds public hospitals with dialysis patients, but leaves the medical professional with a clear conscience, since preserving life at any cost would be the "mission" always taught in undergraduate and graduate courses in medicine.

The Brazilian Constitution of 1988, in its article 5 , title II, dealing with "Fundamental Rights and Guarantees", states: all are equal before the law, without distinction of any nature, guaranteeing to Brazilians and foreigners residing in the inviolability of the right to life, liberty, equality, safety and property ${ }^{4}$.

On the other hand, when patients refuse or abandon dialysis treatment, health professionals experience conflicting ethical issues related to the right to die with dignity. Although less common than the lack of vacancies, this situation has been increasingly frequent and raises, from the religious, philosophical and legal perspectives, discussions about the meanings of life and death, autonomy and terminality. These are precisely the themes of this article, which does not intend and could not establish a consensus but exposes the main points of view on the subject, stimulating the debate, in the most rational way possible, in order to protect health professionals and, especially, the interests of patients. To this end, a literature review on the subject was performed.

\section{Dialysis and quality of life}

The relatively recent concept of quality of life is defined by the World Health Organization as the subjective perception of the individual's position in life, in the context of the culture and value system in which they live and in relation to their goals, expectations, standards and concerns ${ }^{5}$. It is a complex and comprehensive conception that 
incorporates physical health, psychological state, level of independence, social interactions, personal beliefs and the relationships of the individual with the environment.

In practice, there are two types of dialysis: hemodialysis and peritoneal dialysis. The first requires the patient to go to a health facility, usually three times a week, to conduct four-hour sessions on average. This procedure depends on a complex technological apparatus that involves hemodialysis machines and a water treatment system; venous access (native arteriovenous fistula, vascular prosthesis, temporary or long-term catheter); cardiopulmonary bypass and artificial dialyzer as a semipermeable membrane, which allows the passage of nitrogenous waste and electrolytes from the blood to the dialysis bath, due to concentration difference, and also removes excess water, due to pressure difference.

Peritoneal dialysis is performed daily at home by the patient himself and trained family members. It does not depend on much technology: it requires the implantation of a flexible catheter in the peritoneal cavity, through which the dialysis bath will be infused and removed, in the amount and frequency determined by the nephrologist. In this case, the semipermeable membrane is the peritoneum itself; solute withdrawal occurs due to the difference in concentration between the blood of the peritoneal capillaries and the infused fluid, and water withdrawal occurs due to the osmotic power of glucose contained in the dialysis bath ${ }^{1}$.

Both hemodialysis and peritoneal dialysis are related to the poor quality of life of patients, being the elderly and diabetics the most affected. Using standardized questionnaires such as the SF-36, several studies on dialysis and quality of life have shown impairment in all dimensions surveyed: functional capacity, pain, general health, vitality, physical, social, emotional and mental health ${ }^{6,7}$. From a psychological point of view, machine dependency, limited freedom and lack of perspective are linked to frequent depression conditions $^{8}$.

Moreover, even in the SUS, the socioeconomic impact related to dialysis treatment is great. To be closer to hemodialysis services, many patients and family members need to relocate, leaving their social life and built networks. Added to this is the damage of having to leave work activities to live on government benefits, in a situation of great vulnerability. Those who remain in their municipalities have to face long and stressful trips to distant dialysis centers, often in danger on unpaved roads and in poorly maintained vehicles.

Thus, despite the efforts of health teams and even being essential to maintain the life of the patients, this therapy is associated with suffering. For this reason, some patients even prefer death to the beginning or continuation of the treatment.

\section{Human dignity, autonomy and the right to die}

Human dignity is the fundamental principle of the democratic rule of law, established in item III of article 1 of the Brazilian Constitution of $1988^{9}$. Thus, the right to life is not enough, it is necessary to ensure that it is lived with dignity ${ }^{10}$. Moreover, considering that death is a part of life, through the processes of being born, growing, aging and dying, some authors interpret that the right to die would be implicit in the constitutional text ${ }^{11-13}$. According to this idea, having the right to life does not mean being forced to live, since people may choose not to exercise that right.

In 2007, anthropologist Debora Diniz ${ }^{14}$ directed the documentary "Solitário anônimo" ("Anonymous Loner") which tells the story of a gentleman who simply wanted to "die in peace." Following a plan, this elderly man lived alone in a small town in the interior of Brazil and, far from anyone known, decided to stop eating. However, the local health team prevented him from achieving his goal: finding him in an advanced stage of malnutrition and dehydration, they transferred him to the nearest referral hospital.

From then on, a real clash was struck between the unidentified gentleman struggling to exercise his right to die with dignity, and the hospital health team, who imposed treatment and procedures on him, violently disrespecting his will and autonomy ${ }^{14}$. According to Orlando, quoted by Damasceno and Vasconcelos, to fight blindly and stubbornly to keep a patient alive often means to condemn them (and their family and friends) to a miserable existence far below the dignity to which every human being is entitled. We should not aspire to life at any price, but to life with quality ${ }^{15}$.

This film proposes a reflection on the illdefined boundaries between beneficence and nonmaleficence (what is good and bad for this - and any other - individual?) and about the importance of autonomy as a measurement of dignity. Considered 
one of the main foundations of bioethics, the principle of autonomy was incorporated by the Code of Medical Ethics in 2009, through the Resolution of the Conselho Federal de Medicina - Brazilian Federal Council of Medicine (CFM) 1,931, guaranteeing the patient's freedom to participate in the related diagnostic and therapeutic decisions to your clinical condition. That is, they can accept or decline the options presented by the physician, according to their will ${ }^{16}$.

In early 2017, a sentence was handed down against a 22-year-old man who, after five months of hemodialysis sessions, decided to abandon treatment because he considered it "painful" and "with no prospect of cure". The mother appealed to the court, which determined the partial and provisional interdiction of her son and forced him to resume hemodialysis therapy ${ }^{17}$. This decision reveals confusion between vulnerability and disability and ignorance of the effects of the Disabled Persons Statute ${ }^{18}$. Federal Law $13,146 / 2015$ limits interdiction to acts related to property and business rights, so that persons with disabilities maintain control over existential aspects of their life, such as the right to their own body, sexuality, marriage, privacy, education, health, work and voting. Ultimately, the ruling disregards this young man's autonomy and right to refuse treatment ${ }^{19,20}$.

A different decision took place in 2011 when a Porto Alegre judge dismissed a request from a private hospital in Rio Grande do Sul that insisted on subjecting an 82-year-old woman to hemodialysis sessions, even against her will ${ }^{21}$. It seems that the patient's age is a relevant criterion not only for court decisions but for public opinion in general.

An article published in The New York Times in March 201522, "Learning to say no to dialysis," tells the story of a 74-year-old man who, upon receiving from the doctor the news that he needed to start dialysis treatment, simply opted for refuse it: "I don't want to waste my time doing this." Even though he died a year and a half after this decision, he fully exercised the right not to undergo treatment against his will.

Perhaps the most critical moment of this ethical conflict occurs when the patient refuses urgent dialysis, that is, with imminent risk of death. This situation resembles, with due proportions, that of urgent blood transfusions in patients who are Jehovah's Witnesses, when another right, religious liberty, comes into play ${ }^{23}$. In both cases, medical professionals find themselves in a difficult dilemma: on the one hand, the respect for the autonomy of the patient; on the other, the risk of being submitted to an ethical-legal process for the omission of help.

\section{Terminality}

In 2007, the Revista Brasileira de Cancerologia (Brazilian Journal of Cancerology) published a scientific article that analyzed hemodialysis in cases of renal failure due to bilateral ureteral obstruction as a consequence of advanced cervical cancer. The conclusion of the study was that dialysis treatment, in this case, is a form of therapeutic obstinacy, ineffective and unable to provide a better quality of life for patients ${ }^{24}$.

To deepen this theme of terminality, it is important to differentiate the concepts of euthanasia, assisted suicide, dysthanasia and orthothanasia. The first consists in providing for the anticipation of the death of an individual suffering from an incurable disease that produces intolerable suffering. In the case of assisted suicide, the terminally ill person himself, with unbearable pain and a prediction of fewer than six months of survival, consciously enlists the help of someone they trust to put a suicide drug or other similar means at their fingertips. Dysthanasia, on the other hand, is characterized by an exaggerated prolongation of the death process of a terminally ill patient or of useless treatment that is not intended to prolong life, but rather the death process ${ }^{25}$, while orthothanasia predicts natural death at the right time without useless artificial prolongation. The latter is advocated in article 1 of Resolution CFM 1,805/2006: The physician is allowed to limit or suspend procedures and treatments that prolong the life of terminally ill patients under severe and incurable disease, respecting the will of the person or their legal representative ${ }^{26}$.

Often the patient is not in the physical and mental condition to make decisions, and this responsibility is delegated to family members. In order to preserve their autonomy in these cases, there are advance directives of will (ADW), a kind of will in the form of a notary document that, according to article 1 of Resolution CFM 1,995/2012, contains a set of wishes, previously and expressly expressed by the patient, about care and treatment that they 
want, or not, to receive when they are unable to freely and autonomously express their will ${ }^{27}$. The ADWs still lack legal regulation on the formalization, the content, the capacity of the granters, the period of validity, and the creation of a national registry ${ }^{28}$.

From a sociocultural perspective, for a significant portion of the Brazilian population, the preservation of life is an almost dogmatic subject, with a strong religious influence, according to which only God could determine death. Although Brazil is a secular state, religious lobbies influence political decisions, and perhaps that is why the country does not yet have specific legislation on dignified death, which would imply respect for the autonomy of terminally ill patients when dialoguing with multidisciplinary team members and family members about decisions on care and treatment ${ }^{29}$.

Still, the House of Representatives is pending Bill 6,715/2009, which proposes the inclusion in the Penal Code of an article authorizing orthothanasia: Art. 136-A. In the context of palliative care applied to terminally ill patients, it is not a crime to refrain from using disproportionate and extraordinary means in the event of imminent and unavoidable death, provided that there is consent from the patient or their spouse, partner, ascendant, descendant or sibling ${ }^{30}$.

Brazil is, therefore, lagging behind other countries that already have ADW legislation, such as Argentina, Uruguay, the United States of America (US) and most European countries ${ }^{31}$. Euthanasia, framed as homicide or assisted suicide, according to articles 121 and 122 of the Brazilian Penal Code, can be legally practiced, for example, in the Netherlands, Belgium and Luxembourg ${ }^{32}$. Assisted suicide, also considered a crime in the same article 122 of the Brazilian penal code, is permitted in these three countries, in addition to Switzerland and some US states (Oregon, Washington, Vermont, Montana, and New Mexico). In other countries, the subject is still a matter of intense debate ${ }^{33}$.

\section{Final considerations}

The main strategy of the nephrologist in the face of the refusal to undergo dialysis should be to establish the best relationship with the patient and family, even in urgent situations, analyzing the interests involved on a case-by-case basis. To this end, the active participation of a cohesive multidisciplinary team becomes essential.

Although there is no specific legislation in Brazil, some CFM resolutions support the physician in respecting the patient's autonomy, although with certain limits, as they do not have the force of law. In such cases, the free and informed consent form is required, which must be signed by the patient, if they have physical and mental conditions, or by their legal guardians.

In 2015, CFM ${ }^{34}$ issued a recommendation encouraging the creation of bioethics committees in hospitals and health care institutions, with the aim of helping to discuss and resolve issues related to morale and ethics in the care of patients. Despite being still rare in the country, these committees represent valuable support and should always be consulted.

Finally, early diagnosis of CKD, which allows outpatient follow-up before dialysis therapy is initiated, is crucial for establishing the relationship of trust between the patient, the family and the health team. In such cases, it is very difficult for the patient to refuse treatment. Similarly, the humanization of care in hemodialysis or peritoneal dialysis programs is of paramount importance so that the patient does not abandon therapy.

\section{Referências}

1. Salgado Filho N, Brito DJA. Doença renal crônica: a grande epidemia deste milênio. J Bras Nefrol [Internet]. 2006 [acesso 17 jun 2017];28(3 Supl 2):1-5. Disponível: http://bit.ly/2XHIMds

2. Sesso RCC, Lopes AA, Thomé FS, Lugon JR, Martins CT. Brazilian chronic dialysis census 2014. J Bras Nefrol [Internet]. 2016 [acesso 18 jun 2017];38(1):54-61. Disponível: http://bit.ly/2ZmIOHU

3. Bastos MG, Kirsztajn GM. Doença renal crônica: importância do diagnóstico precoce, encaminhamento imediato e abordagem interdisciplinar estruturada para melhora do desfecho em pacientes ainda não submetidos à diálise. J Bras Nefrol [Internet]. 2011 [acesso 20 jun 2017];33(1):93-108. Disponível: http://bit.ly/2Rd42Fx

4. Brasil. Constituição da República Federativa do Brasil [Internet]. Brasília; 1988 [acesso 28 ago 2018]. Disponível: https://bit.ly/1bJYIGL

5. The WHOQOL Group 1995. The World Health Organization quality of life assessment (WHOQOL): position paper from the World Health Organization. Soc Sci Med [Internet]. 1995 [acesso 17 jun 2017];41(10):1405. DOI: 10.1016/0277-9536(95)00112-K 
6. Castro M, Caiuby AVS, Draibe SA, Canziani MEF. Qualidade de vida de pacientes com insuficiência renal crônica em hemodiálise avaliada através do instrumento genérico SF-36. Rev Assoc Med Bras [Internet]. 2003 [acesso 20 jun 2017];49(3):245-9. Disponível: http://bit.ly/2R84xR4

7. Terada I, Hyde C. The SF-36: an instrument for measuring quality of life in ESRD patients. EDTNA ERCA J [Internet]. 2002 [acesso 20 jun 2017];28(2):73-6. DOI: 10.1111/j.1755-6686.2002.tb00206.x

8. Nifa $S$, Rudnicki T. Depressão em pacientes renais crônicos em tratamento de hemodiálise. Rev SBPH [Internet]. 2010 [acesso 22 jun 2017];13(1):64-75. Disponível: http://bit.ly/2F7yrAe

9. Brasil. Op. cit. p. 11.

10. Sarlet IW. Dignidade (da pessoa) humana e direitos fundamentais na Constituição Federal de 1988. 7a ed. rev. atual. Porto Alegre: Livraria do Advogado; 2009.

11. Junges JR, Cremonese C, Oliveira EA, Souza LL, Backes V. Reflexões legais e éticas sobre o final da vida: uma discussão sobre a ortotanásia. Rev. bioét. (Impr.) [Internet]. 2010 [acesso 20 jun 2017];18(2):275-88. Disponível: http://bit.ly/2IFk8Uq

12. Friso GL. A ortotanásia: uma análise a respeito do direito de morrer com dignidade. Rev Trib [Internet]. 2009 [acesso 17 jun 2017];98(885):130-53. Disponível: http://bit.ly/2IHcd93

13. Bomtempo TV. A ortotanásia e o direito de morrer com dignidade: uma análise constitucional. Rev Sínt Direito Fam [Internet]. 2011 [acesso 19 jun 2017];13(68):73-92. Disponível: http://bit.ly/2lcSwqP

14. Solitário anônimo [Internet]. Direção: Debora Diniz. Ano de lançamento: 2010 [acesso 17 jun 2017]. País: Brasil. Idioma: Português. Duração: 18 min. Disponível: http://bit.ly/2MNS8TX

15. Damasceno MLM, Vasconcelos MC. A ortotanásia e o direito fundamental implícito de morrer dignamente. publicaDireito [Internet]. [s.d.] [acesso 20 jun 2017]. Disponível: http://bit.ly/2F8u7R9

16. Conselho Federal de Medicina. Resolução CFM no 1.931, de 24 de setembro de 2009. Aprova o Código de Ética Médica. Diário Oficial da União [Internet]. Brasília, 28 nov 2009 [acesso 20 jun 2017]. Seção 1. Disponível: http://bit.ly/2QhJQlb

17. Tomazela JM. Mãe luta na Justiça para obrigar filho a fazer tratamento que pode evitar morte. $O$ Estado de S. Paulo [Internet]. 16 fev 2017 [acesso 28 ago 2019]. Disponível: https://bit.ly/2Lc7wFO

18. Brasil. Lei no 13.146, de 6 de julho de 2015. Institui a Lei Brasileira de Inclusão da Pessoa com Deficiência (Estatuto da Pessoa com Deficiência). Diário Oficial da União [Internet]. Brasília, 7 jul 2015. Disponível: https://bit.ly/2numMRn

19. Dadalto L, Pimentel W. Direito à recusa de tratamento: análise da sentença proferida nos autos $n$ 은 201700242266 - TJGO. RBDCivil [Internet]. 2018 [acesso 22 jun 2018];15:159-75. Disponível: http://bit.ly/2wSVmul

20. Oliveira EQ Jr. A recusa de tratamento médico. JusBrasil [Internet]. 6 mar 2017 [acesso 17 jun 2017]. Disponível: http://bit.ly/2MMXSxp

21. Para a lei, viver é um direito e não uma obrigação. Folha de S.Paulo [Internet]. 2 jun 2011 [acesso 20 jun 2017]. Disponível: http://bit.ly/2XL6OV0

22. Span P. Learning to say no to dialysis. The New York Times [Internet]. Health; 27 mar 2015 [acesso 20 jun 2017]. Disponível: https://nyti.ms/2MlhOkO

23. Martins G. Fiel tem direito de recusar transfusão de sangue. Consultor Jurídico [Internet]. 8 maio 2010 [acesso em 21 jun 2017]. Disponível: http://bit.ly/2WEW9d8

24. Silva CHD, Schramm FR. Bioética da obstinação terapêutica no emprego da hemodiálise em pacientes portadoras de câncer do colo do útero invasor, em fase de insuficiência renal crônica agudizada. Rev Bras Cancerol [Internet]. 2007 [acesso 22 jun 2017];53(1):17-27. Disponível: http://bit.ly/2KOgOVO

25. Diniz MH. O estado atual do biodireito. 9a ed. São Paulo: Saraiva; 2014.

26. Conselho Federal de Medicina. Resolução CFM no 1.805, de 28 de novembro de 2006. Na fase terminal de enfermidades graves e incuráveis é permitido ao médico limitar ou suspender procedimentos e tratamentos que prolonguem a vida do doente, garantindo-lhe os cuidados necessários para aliviar os sintomas que levam ao sofrimento, na perspectiva de uma assistência integral, respeitada a vontade do paciente ou de seu representante legal. Diário Oficial da União [Internet]. Brasília, p. 169, 28 nov 2006 [acesso 23 jun 2017]. Seção 1. Disponível: http://bit.ly/2QhJQlb

27. Conselho Federal de Medicina. Resolução CFM no 1.995, de 31 de agosto de 2012. Dispõe sobre as diretivas antecipadas de vontade dos pacientes. Diário Oficial da União [Internet]. Brasília, p. 269-70, 31 ago 2012 [acesso 15 jun 2017]. Seção 1. Disponível: http://bit.ly/2MLMRfl

28. Dadalto L, Tupinambás U, Greco DB. Diretivas antecipadas de vontade: um modelo brasileiro. Rev. bioét. (Impr.) [Internet]. 2013 [acesso 15 jun 2017];21(3):463-76. Disponível: http://bit.ly/2KJRRPe

29. Moreira MADM, Costa SFG, Cunha MLDM, Zaccara AAL, Negro-Dellacqua M, Dutra F. Testamento vital na prática médica: compreensão dos profissionais. Rev. bioét. (Impr.) [Internet]. 2017 [acesso 20 jun 2017];25(1):168-78. DOI: 10.1590/1983-80422017251178

30. Brasil. Senado Federal. Projeto de Lei no 6.715/2009. Altera o Decreto-Lei 2.848, de 7 de dezembro de 1940 (Código Penal), para excluir de ilicitude a ortotanásia [Internet]. Câmara dos Deputados. Brasília, 2009 [acesso 20 jun 2017]. Disponível: http://bit.ly/2KLS3gY

31. JC debate: o direito de escolher. Jornalismo TV Cultura [Internet]. 22 fev 2017 [acesso 21 jun 2017]. Vídeo: 27:24. Disponível: http://bit.ly/2WDRLLc

32. Brasil. Decreto-Lei no 2.848, de 7 de dezembro de 1940. Código Penal. Diário Oficial da União. Brasília [Internet], 31 dez 1940 [acesso 14 jun 2019]. Disponível: https://bit.ly/2kZsIzx

33. Perasso V. Suicídio assistido: que países permitem ajuda para morrer? BBC Brasil [Internet]. 12 set 2015 [acesso 18 jun 2017]. Disponível: https://bbc.in/2WE9Bhp

34. Conselho Federal de Medicina. Recomendação CFM no 1/2015. Recomenda a criação, o funcionamento e a participação dos médicos nos Comitês de Bioética [Internet]. Brasília, 12 mar 2015 [acesso 18 jun 2017]. Disponível: http://bit.ly/2WIAJAH 
Dialysis and the right to die

Participation of the authors

Both authors analyzed the data ans revised the text.

\section{Correspondência}

Rodrigo Alexandre da Cunha Rodrigues - Praça Camilo Salgado, 1, Umarizal CEP 66050-060. Belém/PA, Brasil.

Rodrigo Alexandre da Cunha Rodrigues - Mestrando - rodrigonefrologista@gmail.com

(D) 0000-0001-6094-7042

Érica Quinaglia Silva - Doutora - equinaglia@yahoo.com.br

(iD) 0000-0001-9526-7522 